\title{
PENERAPAN TAKSONOMI BLOOM DAN KRATHWOHL'S PADA APLIKASI RUBRIK PENILAIAN HASIL BELAJAR SISWA DI SAMARINDA UNTUK ASPEK AFEKTIF
}

\author{
Hanifah Ekawati ${ }^{1}$, Wahyuni ${ }^{2}$, Nila Ratna Sari ${ }^{3}$ \\ STMIK Widya Cipta Dharma ${ }^{1,2,3}$ \\ Jl. Prof. M. Yamin No. 25, Samarinda \\ Sur-el : hanifah@wicida.ac.id ${ }^{1}$,wahyuni@wicida.a.c.id, nila@wicida.a.c.id ${ }^{3}$
}

\begin{abstract}
The development of an application for the assessment of learning outcomes in this aspect will help teachers in the teaching and learning process, as well as make it easier for teachers to assess learning outcomes because the rubric is already available for application and there will be output of learning outcomes on the affective aspects of students. In this study using the waterfall model development method. As for what is needed data analysis, needs analysis, technology analysis, user analysis. Design, all data that has been collected in the system design process, so as to facilitate the description of the system and clarify the description of the existing system. Implementation, after doing the analysis and design, then the implementation is carried out, namely the development of the system, in this case starting the program. This application uses three users, namely the TU user, the Teacher user, the Homeroom user to view student data reports and student affective learning outcomes reports. The result of this research is a desktopbased application for assessing student learning outcomes in the affective aspect.
\end{abstract}

Keywords: Learning Outcomes, Affective, Application, Waterfall

\begin{abstract}
Abstrak : Pengembangan aplikasi rubrik penilaian hasil belajar pada aspek afektif ini akan membantu guru dalam mengevaluasi proses belajar mengajar, serta mempermudah guru menilai hasil belajar karena rubrik telah tersedia diaplikasi ini dan akan terdapat output penilaian hasil belajar pada aspek afektif siswa. Pada penelitian ini menggunakan motode pengembangan model air terjun (waterfall). Adapun yang diperlukan analisis data, analisis kebutuhan, analisis teknologi, analisi user. Desain, seтиa data yang telah terkumpul dilakukan proses desain sistem, sehingga dapat mempermudah dalam penggambaran sistem dan memperjelas gambaran sistem yang ada. Implementasi, setelah melakukan analisis dan desain, maka dilakukan implementasi yaitu pembangunan sistem, dalam hal ini difokuskan pada pembuatan program. Aplikasi ini menggunakan tiga user yaitu user TU, user Guru user Wali Kelas untuk melihat laporan data siswa dan laporan nilai hasil belajar afektif siswa. Hasil penilitian ini adalah aplikasi berbasis dekstop untuk penilaian hasil belajar siswa pada aspek afektif.
\end{abstract}

Kata kunci: Hasil Belajar, Afektif, Aplikasi, Waterfall

\section{PENDAHULUAN}

Penilaian afektif atau sikap adalah penilaian terhadap reaksi seseorang atau peserta didik tentang mata pelajaran selama proses pembelajaran berlangsung. Masalah afektif dirasakan penting oleh semua orang, namun implementasinya masih kurang. Satuan pendidikan harus merancang kegiatan pembelajaran yang tepat agar tujuan pembelajaran afektif dapat dicapai. Keberhasilan pendidik melaksanakan pembelajaran ranah afektif dan keberhasilan peserta didik mencapai kompetensi afektif perlu dimulai. Oleh karena itu perlunya penilaian hasil belajar afektif dalam mengevaluasi hasil belajar karena tidak cukup hanya menilai hasil belajar dari aspek kognitif dan psikomotorik saja.

Pembelajaran juga berarti meningkatkan kemampuan-kemampuan kognitif, afektif, dan 
keterampilan siswa. Kemampuan-kemampuan tersebut dikembangkan bersama dengan pemerolehan pengalaman-pengalaman belajar yang sudah pernah didapat sebelumnya. Dengan menghadapi sejumlah siswa, berbagai pesan yang terkandung dalam bahan ajar, peningkatan kemampuan siswa, dan proses perolehan pengalaman, maka setiap guru memerlukan pengetahuan tentang model-model pembelajaran. Hasil belajar adalah perubahan prilaku siswa secara keseluruhan dan kemampuan yang dimiliki siswa setelah menerima pengalaman belajarnya. Hasil yang dicapai siswa sebagai bukti keberhasilan proses belajar mengajar dalam bidang pengetahuan keterampilan, sikap dan nilai. [1]

Ranah Afektif mencakup segala sesuatu yang terkait dengan emosi, misalnya perasaan, nilai, penghargaan, semangat, minat, motivasi, dan sikap. Dalam mengukur hasil belajar kawasan afektif termasuk sukar karena menyangkut kawasan sikap dan apresiasi Disamping itu kawasan afektif juga sulit dicapai pada pendidikan formal, karena pada pendidikan formal perilaku yang nampak dapat diasumsikan timbul sebagai akibat dari kekakuan aturan, disiplin belajar, waktu belajar dan norma-norma lainnya. Dengan demikian dapat dikatakan bahwa perilaku seperi itu timbul bukan karena siswa telah sadar dan menghayati betul tentang kebutuhan akan sikap dan perilaku tersebut, tetapi dilakukan karena sekedar untuk memenuhi aturan dan disiplin saja agar tidak mendapat hukuman. Evaluasi afektif berkaitan dengan pembentukan dan perubahan sikap. Dalam taksonomi Benjamin S. Bloom ada tiga ranah pendidikan, yaitu ranah berpikir (cognative domain), ranah nilai atau sikap (affective domain), dan ranah keterampilan (psychomotor domain) Bloom menawarkan konsepnya di Boston pada tahun 1948, perkembangan selanjutnya, Bloom mengembangkan cognitive domain pada tahun 1956, sedangkan affective domain dikembangkan Bloom bersama David R. Krathwohl dan Bertram B. Masia pada 1964, selanjutnya psycho-motor domain oleh Simpson pada 1972. [2]

Kawasan afektif merupakan tujuan yang berhubungan dengan perasaan emosi sistem nilai dan sikap hati (attitude) yang menunjukan penerimaan atau penolakan terhadap sesuatu, apresiasi (penghargaan) dan penyesuaian perasaan sosial. We attempt evaluating affective outcome when we encourage students to express their feeling, attitudes and values about the topics discussed in class. Tujuan afektif disebut sebagai minat, sikap hati nurani, sikap menghargai, sistem nilai, dan kecenderungan emosi. Tingkatan ranah afektif menurut taksonomi Krathwohl ada lima yaitu receiving(attending), responding, Valuing, Organization, dan Characterization by a value complex. [2]

Berdasarkan latar belakang di atas, pengembangan aplikasi rubrik penilaian hasil belajar pada aspek afektif ini akan membantu guru dalam mengevaluasi proses belajar mengajar, serta mempermudah guru menilai hasil belajar karena rubrik telah tersedia diaplikasi ini dan akan terdapat output penilaian hasil belajar pada aspek afektif siswa. Berdasarkan latar belakang di atas, 
pengembangan aplikasi rubrik penilaian hasil belajar pada aspek afektif ini akan membantu guru dalam mengevaluasi proses belajar mengajar, serta mempermudah guru menilai hasil belajar karena rubrik telah tersedia diaplikasi ini dan akan terdapat output penilaian hasil belajar pada aspek afektif siswa.

Penelitian tentang hasil belajar Afektif telah banyak dilakukan antara lain:

1. Pengembangan rubrik hasil belajar matematika untuk aspek kognitif pada materi bangun datar. [1]

2. Penggunaan instrument non-tes dalam pembelajaran bahasa indonesia untuk menilai ranah afektif siswa sdn karangsari 1 tanggerang. [3]

3. Intrument Evaluasi non-tes dalam penilaian hasil belajar ranah afektif dan psikomotorik.[4]

4. Penerapan instrumen penilaian ranah afektif siswa pada praktikum kimia di Sekolah. [5]

Pada Penelitian pertama meneliti tentang pengembangan rubrik hasil belajar pada aspek kognitif. Penelitian ini mengembangkan instrument penilaian juga menggunakan Teori Taksonomi Bloom. Hasil penelitian ini adalah pengembangan rubrik hasil belajar matematika pada aspek kognitif dengan cara menerapkan indikator pada teori Bloom yaitu: Knowledge, Comprehension, Application, Analysis, Synthesis \& Evaluation. Dan terdapat perbedaan hasil belajar matematika antara tipe think pair share dan tipe two stay two stray. Pada Penelitian Ina Magdalena, meneliti tentang penilaian ranah afektif dalam pembelajaran Bahasa Indonesia dengan mengacu pada Teori Bloom dan
Krathwohl's dan menggunakan instrument non test yaitu observasi, wawancara, angket dan dokumen teknik daftar cek. Penelitian menggunakan metode kuantitatif untuk mengetahui bagaimana penggunaan non test dalam pembelajaran Bahasa Indonesia untuk menilai ranah afektif. Serta untuk mengetahui hasil yang digunakan untuk penelitian ini menggunakan model pengembangan Thiagarajian, semmel \& Semmel atau sering disebut dengan Four-D. Hasil dari penelitian ini yaitu penggunaan non test dalam pembelajaran Bahasa Indonesia sangat baik untuk menentukan dan membantu guru dalam melaksanakan penilaian akhir atau hanya sebagai pengingat tentang apa saja yang sudah dilakukan siswa.

Pada penelitian Rinto Hasiholan Hutapea, mengembangkan intrumen penilaian hasil belajar afektif dan psikomotorik dengan menggunakan metode survei dan studi Pustaka. Dimana dijelaskan bahwa untuk mengukur dan menilai hasil belajar ranah afektif dan psikomotorik, jenis intrument yang tepat digunakan adalah non-tes. Pada penelian Luki Yunita dkk, meneliti tentang penerapan intrumen penilaian ranah afektif siswa pada praktikum kimia di Sekolah. Penelitian dilakukan melalui tiga tahapan yaitu studi pendahuluan, pengembangan intrumen dan uji intrumen penelitian. Hasil penelitian uji intrumen penelitian dengan memberikan instrument kepada guru dan siswa untuk merespon instrument penilaian ranah afektif yang dikembangkan. Hasil yang diperoleh masuk kategori baik dalam pemenuhan syarat instrument penilaian yang baik menurut Peraturan Menteri Pendidikan dan Kebudayaan 
tentang Standar Penilaian. Kesimpulan dari ketiga kajian empirik di atas adalah kajian empirik tersebut meneliti tentang penilaian hasil belajar siswa pada aspek afektif dengan mengembangkan intrumen penilaian berupa instrument non tes. Serta pada ketiga penelitian tersebut merujuk pada dasar taksonomi Bloom dan Krathwohl's.

Pada penelitian ini juga akan mengembangkan instrument penilaian hasil belajar pada aspek afektif dengan rubrik penilaian aspek afektif berupa aplikasi desktop sehingga mempermudah guru maupun dosen dalam menilai hasil belajar. Hasil yang akan dicapai dalam penilitian ini adalah aplikasi rubrik penilaian hasil belajar pada aspek afektif dengan merujuk pada Taksonomi Bloom dan Krathwohl's.

Taksonomi berasal dari dua kata dalam bahasa Yunani yaitu tassein yang berarti mengklasifikasi dan nomos yang berarti aturan. Ranah Afektif mencakup segala sesuatu yang terkait dengan emosi, misalnya perasaan, nilai, penghargaan, semangat, minat, motivasi, dan sikap. Lima kategori ranah ini diurutkan mulai dari perilaku yang sederhana hingga yang paling kompleks. [6]

Kategori pertama penerimaan yaitu kemampuan untuk menunjukkan atensi dan penghargaan terhadap orang lain. Kategori kedua rensponsif yaitu kemampuan berpartisipasi aktif dalam pembelajaran dan selalu termotivasi untuk segera bereaksi dam mengambil Tindakan atas suatu kejadian. Ketiga kategori Nilai diri yaitu kemampuan menunjukkan nilai yang dianut untuk membedakan mana yang baik dan kurang baik terhadap suatu kejadian/objek, dan nilai tersebut dieksperisikan dalam prilaku. Keempat kategori Organisasi yaitu kemampuan membentuk sistem nilai dan budaya organisasi dengan mengharmonisasikan perbedaan nilai. Kelima kategori karakterikstik yaitu kemampuan mengendalikan perilaku berdasarkan nilai yang dianut dan memperbaiki hubungan interpersonal dan sosial.

Langkah-langkah yang harus digunakan dalam menerapkan Taksonomi Bloom adalah sebagai berikut: (1) Tentukan tujuan pembelajaran (2) Tentukan kompetensi pembelajaran yang ingin dicapai apakah peningkatan knowledge, skills atau attitude. Dalam hal ini perlu dipertimbangkan karakteristik mata pelajaran dan peserta didik (3) Tentukan ranah kemampuan intelektual sesuai dengan kompetensi pembelajaran. Ranah Afektif: Kategorikan ranah tersebut, apakah termasuk penerimaan, responsif, nilai yang dianut (nilai diri), Organisasi dan karakterisasi. (4) Gunakan kata kerja kunci yang sesuai, untuk menjelaskan instruksi kedalaman materi, baik pada tujuan program diklat, kompetensi dasar dan indikator pencapaian.

Tabel 1. Krathwohl's Taxonomy of Affective Objectives

\begin{tabular}{|c|c|}
\hline Level & Description \\
\hline $\begin{array}{l}\text { Receiving } \\
\text { (attending) }\end{array}$ & $\begin{array}{l}\text { Being aware of and willing to } \\
\text { attend to something. }\end{array}$ \\
\hline Responding & $\begin{array}{l}\text { Actively participating in an } \\
\text { activity or process. }\end{array}$ \\
\hline Valuing & $\begin{array}{l}\text { Assigning value or worth to an } \\
\text { activity or idea. }\end{array}$ \\
\hline Organization & $\begin{array}{l}\text { Ideas and values become } \\
\text { internalized and organized } \\
\text { into one's personal system of } \\
\text { values and beliefs. }\end{array}$ \\
\hline $\begin{array}{l}\text { Characterization by } \\
\text { a value complex }\end{array}$ & $\begin{array}{l}\text { Individual values are } \\
\text { exemplified in a characteristic } \\
\text { set of behaviors and actions. }\end{array}$ \\
\hline
\end{tabular}




\section{METODOLOGI PENELITIAN}

Pada penelitian ini menggunakan motode pengembangan model air terjun (waterfall). Analisis adalah tahap awal adalah tahap awal yang harus dilakukan untuk mengidentifikasi berbagai permasalahan yang ada pada sistem serta kebutuhan bagi pemakainya. Adapun yang diperlukan analisis data, analisis kebutuhan, analisis teknologi, analisi user. Desain, semua data yang telah terkumpul dilakukan proses desain sistem, sehingga dapat mempermudah dalam penggambaran sistem dan memperjelas gambaran sistem yang ada. Implementasi, setelah melakukan analisis dan desain, maka dilakukan implementasi yaitu pembangunan sistem, dalam hal ini difokuskan pada pembuatan program.

\subsection{Subjek dan Objek Penelitian}

Subjek dalam penelitian ini adalah penggunaan aplikasi penilaian hasil belajar siswa pada aspek afektif. Sedangkan objek penelitian ini adalah penerarapan taksonomi bloom dan krathwohl's pada aplikasi rubrik penilaian hasil belajar siswa di samarinda untuk aspek afektif.

\subsection{Teknik Pengumpulan Data}

Data yang dikumpulkan terdiri atas data sekunder dan data primer. Data primer berasal dari lokasi pengkajian secara langsung, yang dilakukan melalui wawancara. Sedangkan data sekunder diperoleh dengan mempelajari studi literatur yang berupa aturan-aturan tertulis atau dokumen yang ada kaitannya judul penelitian.

\subsection{Teknik Analisis data}

Dalam menganalisis data, beberapa data yang dibutuhkan untuk membuat sebuah Aplikasi Penilaian Hasil Belajar Afektif pada SMP Negeri 19 Samarinda.

\section{HASIL DAN PEMBAHASAN}

\subsection{Analisis Data}

Analisis data merupakan kegiatan pengumpulan informasi mengenai data-data yang digunakan untuk membuat sebuah aplikasi penilaian hasil belajar afektif.

\subsection{Analisis Kebutuhan}

Analisis kebutuhan mencakup berbagai hal yang dibutuhkan dalam sebuah sistem. Berdasarkan analisis yang dilakukan untuk membangun Aplikasi Penilaian Hasil Belajar Afektif diperlukan hal-hal sebagai berikut:

\section{A. Input Data Siswa}

Untuk menginput data siswa yang akan dilakukan penilaian afektif terhadap siswa SMP Negeri 19 Samarinda.

B. Proses pengolahan penilaian afektif Adapun rubrik pada aspek afektif sebagai berikut:

1. Penerimaan, Kriteria Butir yang dinilai:

a. Siswa dapat menerjemahkan atau menganalisis soal dengan tenang

b. Siswa menyelesaikan soal dengan cara-cara terkontrol/hati-hati

c. Siswa merasa senang menerima soal yang diberikan tanpa tekanan. 


\section{Menanggapi}

a. Siswa menyelesaikan soal sesuai dengan langkah-langkah yang tepat.

b. Siswa antusias/mempunyai rasa ingin dalam menjawab soal.

c. Siswa mengerjakan soal sesuai dengan petunjuk menjawab soal.

3. Percaya diri

a. Siswa konsisten dalam menuliskan jawabannya.

b. Siswa menuliskan langkah-langkah jawaban dengan rapi

c. Siswa yakin dengan jawabannya (tidak banyak mencoret jawaban)

4. Mengatur diri

a. Siswa konsisten dalam penulisan simbol-simbol dengan pengaturannya.

b. Siswa menyelesaikan soal dengan prinsip mendahulukan soal yang lebih mudah

c. Siswa mengerjakan soal secara independent (mandiri).

5. Bertanggung jawab

a. Siswa konsisten dalam penulisan simbol-simbol dengan pengaturannya.

b. Siswa menyelesaikan soal dengan prinsip mendahulukan soal yang lebih mudah.

c. Siswa mengerjakan soal secara independent (mandiri).

Teknik pemberian skor dengan cara memberi skor 0 hingga 3. Setiap pencapaian kriteria bernilai 1, maka jika kriteria butir tidak ada yang memenuhi maka nilai 0 .

\section{Output}

\section{Laporan Data Siswa}

Laporan data siswa berisikan tentang laporan data-data siswa yang pengguna inginkan untuk dijadikan sebuah laporan.

\section{Laporan Nilai Hasil Belajar Afektif Siswa}

Laporan nilai hasil belajar afektif siswa berisikan tentang laporan penilaian hasil belajar afektif siswa siswi yang diinginkan oleh pengguna untuk dijadikan laporan.

Adapun software dan hardware yang digunakan untuk pembuatan Aplikasi Penilaian Hasil Belajar Afektif ini meliputi :

1. Perangkat Keras
a. Processor Inter Core i7
b. Memory minimal $2 \mathrm{~GB}$
c. Hasdisk minimal $80 \mathrm{~GB}$
d. Keyboard dan Mouse
e. Monitor 15.6"
f. Printer

2. Perangkat Lunak
a. Sistem Operasi Windows 7
b. Microsoft Visual Studio Ultimate 2010
c. XAMPP 3.2.2
d. Crystal Report 8.5

Adapun user yang digunakan sebagai berikut : TU, Guru Matematika dan wali kelas.

\subsection{Desain}

Flow Of Document (FOD) yang diusulkan pada gambar 3 dimulai dari data siswa akan di inputkan oleh entitas TU setelah itu data siswa akan di proses. Data siswa yang telah di proses akan masuk ke database tabel data_siswa, setelah itu melakukan proses pembuatan laporan dan akan mengkasilkan laporan data siswa. Proses data siswa juga di berikan ke entitas guru matematika untuk melakukan proses penilaian hasil belajar afektif pada siswa, hasilnya akan di masukkan ke database tabel perhitungan. Setelah itu melakukan proses pembuatan laporan sehingga hasilnya menjadi 
laporan hasil penilaian afektif siswa. Laporan data siswa dan laporan hasil penilaian afektif siswa akan diberikan ke entitas wali kelas.

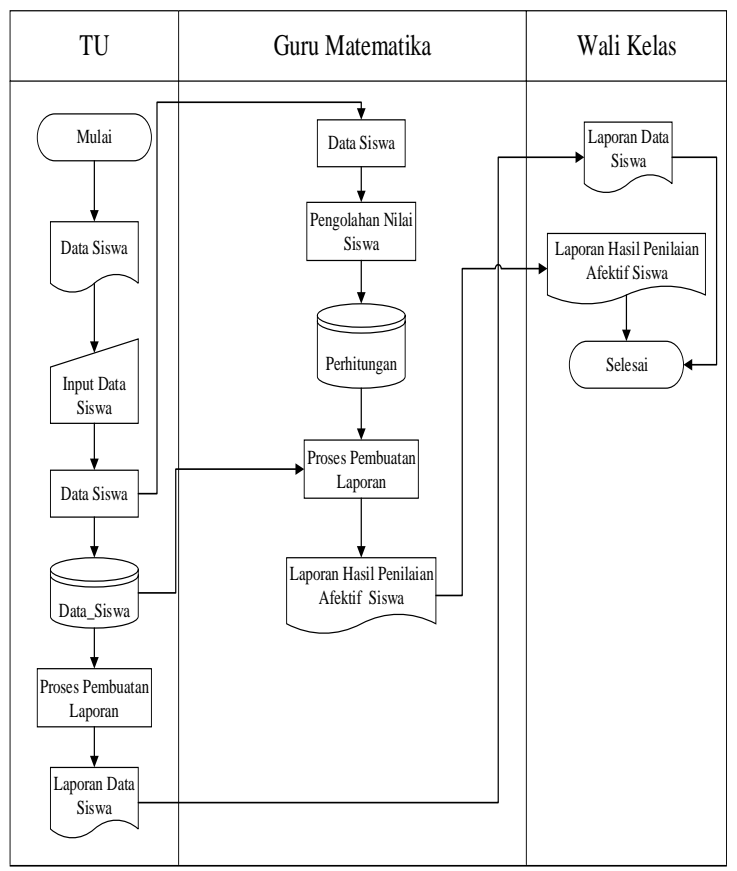

Gambar 1. FOD yang diusulkan

\subsection{Implementasi}

\section{Form Halaman Utama}

Form Halaman Utama adalah tampilan awal dan tampilan utama Aplikasi Penilaian Hasil Belajar Afektif. Terdapat MenuStrip yang didalamnya terdapat item-item seperti Login, dimana item login didalamnya terdapat menu item seperti Login TU, Login Guru Matematika dan Login Wali Kelas. Serta ada item Exit untuk keluar dari aplikasi.

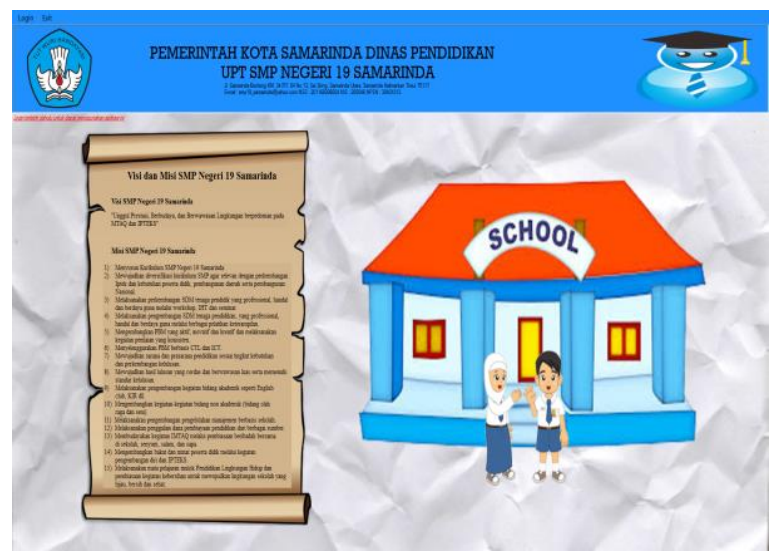

Gambar 2 Form Halaman Utama

\section{Form Halaman Awal User TU}

Form Halaman Awal User TU merupakan form yang akan muncul ketika user TU telah login. Terdapat MenuStrip yang didalamnya terdapat itemitem seperti : Item Edit Admin TU untuk manmpilkan halaman edit user TU, Item Input Data Siswa untuk menampilkan halaman dimana user bisa melakukan input data serta mengedit data siswa, Item Laporan untuk menampilkan halaman laporan data siswa, Item LogOut untuk keluar sebagai user TU, serta Item Exit untuk keluar langsung dari aplikasi. Tampilan Form Halaman Awal User TU dapat dilihat seperti pada gambar 3 .

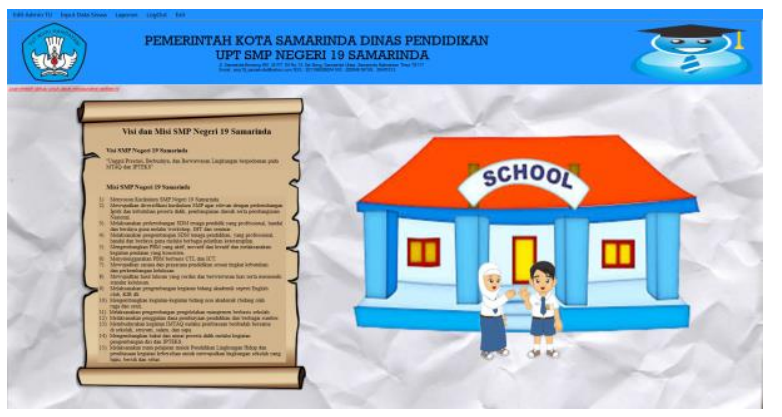

\section{Gambar 3 Form Halaman Awal User TU}

\section{Form Inpt Data Siswa untuk User TU}

Form Input Data Siswa adalah form untuk menambahkan, menghapus, mengedit, mencari data siswa serta form ini hanya bisa di gunakan oleh user TU. Apabila user ingin menambahkan data maka user dapat memilih Button Insert, Button Cancel untuk membatalkan kegiatan yang dilakukan oleh user, Button Save untuk menyimpan data yang ditambahkan maupun yang di edit oleh user, apabila user ingin mengedit suatu data user dapat memilih Button Edit setelah memilih Button Edit maka selanjutnya memasukkan NISN yang akan di edit setelah itu tekan Enter ataupun pilih Button Edit untuk menampilkan data yang akan di edit, Button Delete untuk menghapus data yang di inginkan, 
setelah memilih Button Delete selanjutnya memasukkan NISN yang akan di hapus, untuk Button Search untuk mencari yang diinginkan oleh user, dan Button Done untuk menyelesaikan pencarian data. Dan user dapat melihat keterangan langkah penggunaan dengan memilih tulisan yang berwarna merah, bergaris bawah yang bertuliskan Keterangan Langkah Penggunaan, Button Selesai untuk kembali ke halaman form input data siswa. Pada MenuStrip terdapat Item Home, Item Input Data Siswa, dan Item Laporan. Tampilan Form Input Data Siswa dapat dilihat seperti pada gambar 4 dan 5 tampilan keterangan langkah penggunaan.

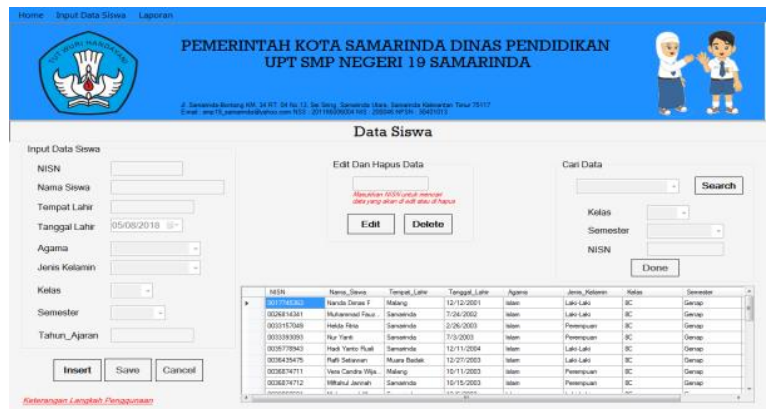

Gambar 4 Form Input Data Siswa

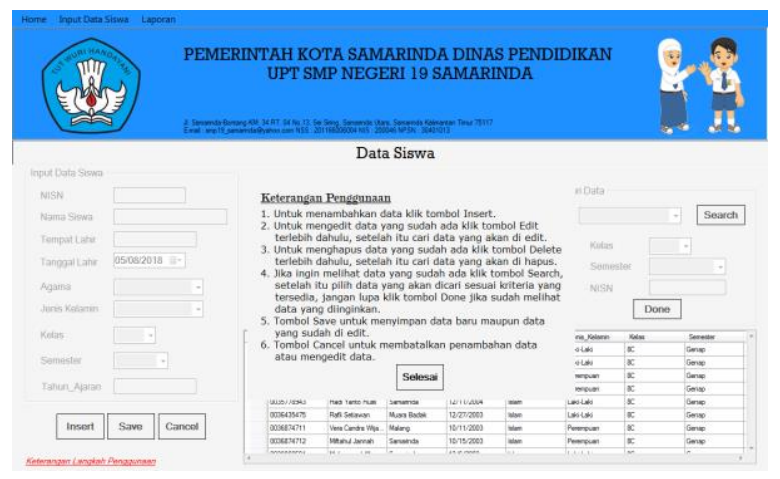

Gambar 5 Tampilan Keterangan

\section{Penggunaan}

4. Form Halaman Awal User Guru Matematika

Form Halaman Awal User Guru Matematika merupakan form yang akan muncul ketika user guru matematika telah login. Terdapat MenuStrip yang didalamnya terdapat item-item seperti : Item Edit Admin Gurum Matematika untuk menampilkan halaman edit user guru matematika, Item Keterangan Penilaian untuk menampilkan Form Keterangan Penilaian, Item Penilaian untuk menampilkan Form Penilaian, Item Laporan untuk menampilkan Form Laporan, Item LogOut untuk keluar sebagai user guru matematika, dan Item Exit untuk keluar langsung dari aplikasi. Tampilan Form Halaman Awal User Guru Matematika dapat dilihat seperti pada gambar 6.

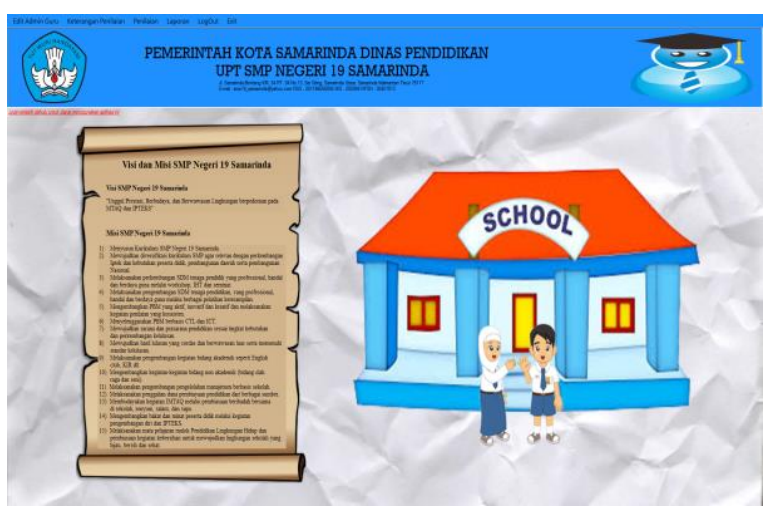

Gambar 6 Form Halaman Awal User Guru

\section{Matematika}

5. Form Keterangan Penilaian untuk User Guru Matematika

Form Keterangan Penilaian adalah form keterangan penilaian yang terdapat Button Penerimaan untuk melihat kriteria penilaian aspek afektif dari kategori penerimaan, Button Menanggapi untuk melihat kriteria penilaian aspek afektif dari kategori menanggapi, Button Percaya Diri untuk melihat kriteria penilaian aspek afektif dari kategori percaya diri, Button Mengatur Diri untuk melihat kriteria penilaian aspek afektif dari kategori Mengatur diri, Button Bertanggung Jawab untuk melihat kriteria penilaian aspek afektif dari kategori bertanggung jawab. Dan terdapat MenuStrip yang didalam terdapat Item Home, Keterangan Penilaian, Penilaian, dan Laporan. Tampilan Form Keterangan Penilaian dapat dilihat seperti pada gambar 7 . 


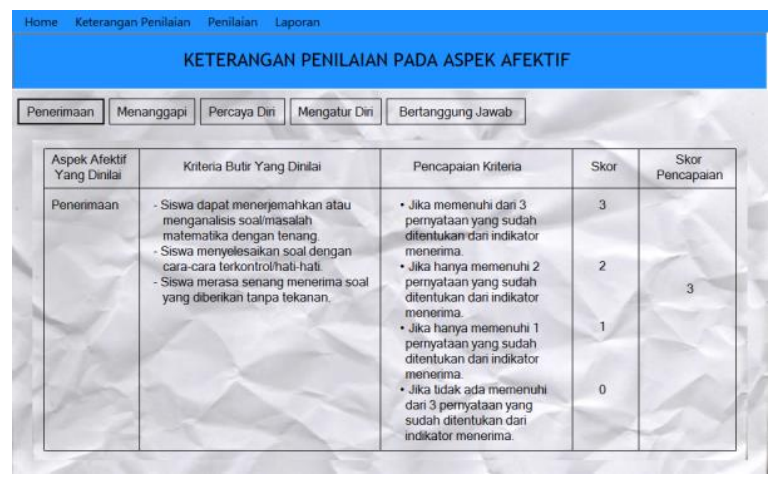

\section{Gambar 7 Form Keterangan Penilaian untuk}

\section{User Guru Matematika}

\section{Form Penilaian untuk User Guru Matematika}

Form Penilaian adalah form untuk melakukan penilaian terhadap siswa dengan kriteria-kriteria pada aspek Afektif yang dilakukan oleh user guru matematika. Button Insert untuk memilih data yang akan dinilai oleh user, setelah itu masukkan NISN untuk mencari data yang akan di edit setelah itu tekan Enter ataupun pilih Button Search untuk menampilkan data. Button Cancel untuk membatalkan kegiatan yang sedang berjalan. Button Save untuk menyimpan nilai dari data yang telah di pilih oleh user. Buttukn Next untuk melanjutkan penilaian dan Button Hasil untuk menampilkan nilai akhir siswa. Dan terdapat MenuStrip yang didalam terdapat Item Home, Keterangan Penilaian, Penilaian, dan Laporan. Tampilan Form Penilaian dapat dilihat seperti pada gambar 8 .

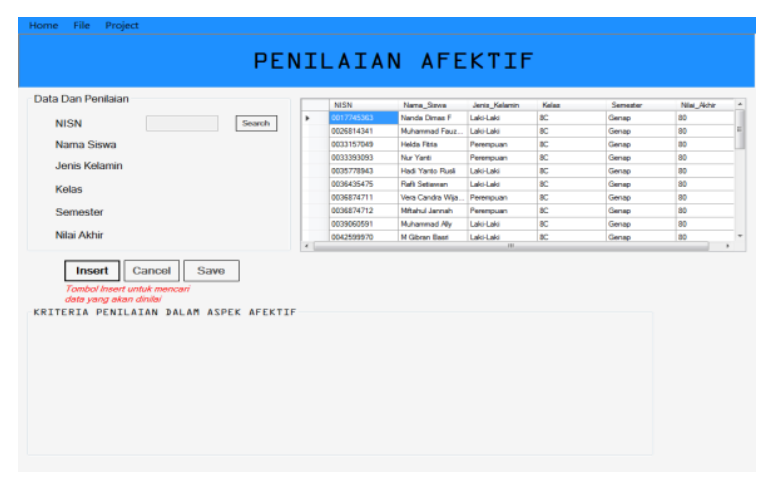

Gambar 8 Form Penilaian untuk User Guru
Gambar 9 akan memunculkan kriteria-kriteria dari penilaian hasil belajar afektif. Button next untuk melanjutkan ke kriteria selanjutnya sampai akhir akan menampilakn 5 kriteria dan pada akhir kriteria akan ada Button Hasil untuk mendapatkan hasilnya. Dan untuk mendapatkan hasil setiap kriteria nilai maksimum adalah 3, karena ada 5 kriteria pada aspek afektif yang telah di validasi sehingga nilai maksimum kesemua kriteria adalah 15. Hasil pilihan dari tiap tiap kriteria akan di bagi dengan 15 dan dikalikan 100, sehingga mendapatkan hasil penilaian pada aspek afektif. Serta gambar 10 merupakan gambar ketika guru matematika telah memilih Button Hasil sehingga nilai akhir akan di dapatkan.

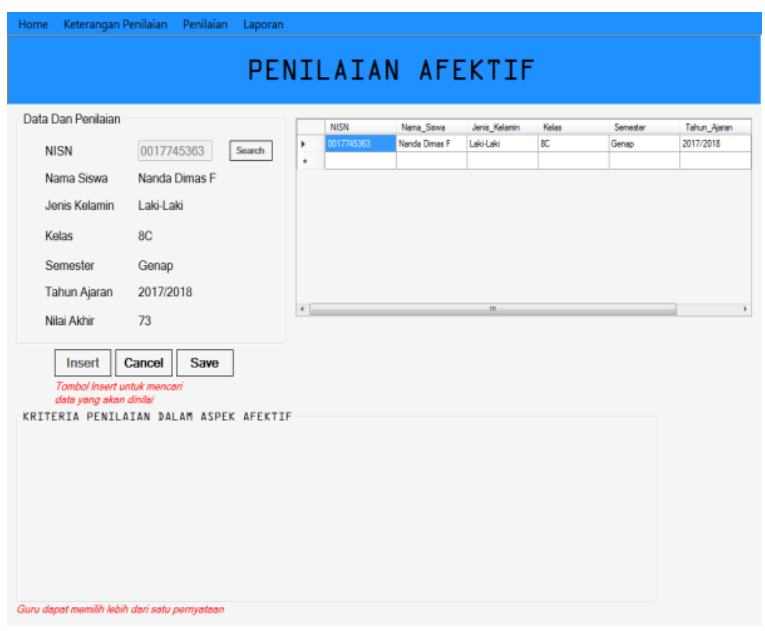

\section{Gambar 9 Form Penilaian untuk User Guru}

\section{Matematika}

7. Form Laporan Nilai Hasil Belajar Afektif Siswa untuk User Guru Matematika

Form Laporan Data Siswa ini bisa ditampilkan oleh user Guru Matematika, pada form ini user Guru Matematika bisa mencetak laporan nilai hasil belajar afektif siswa. Tampilan Form Laporan Data Siswa dapat dilihat seperti pada gambar 10 serta gambar 11 hasil laporan hasil belajar afektif.

\section{Matematika}




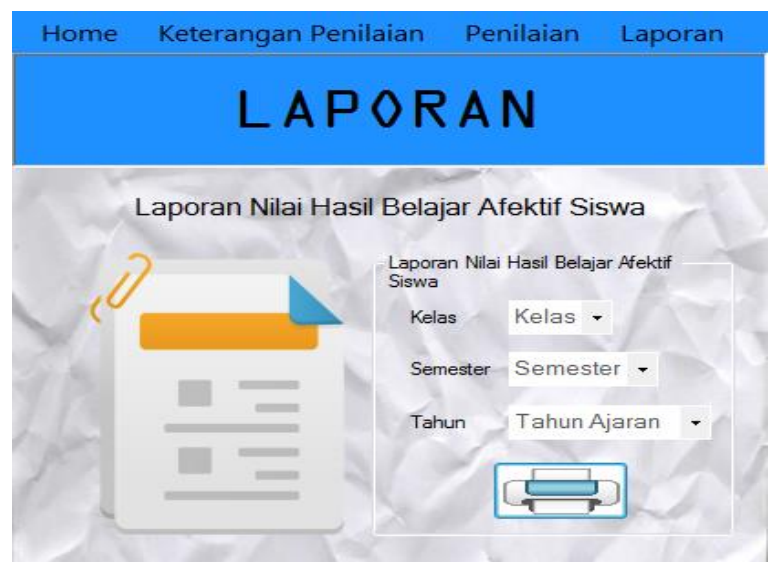

Gambar 10 Form Laporan Nilai Hasil Belajar Afektif Siswa untuk User Guru Matematika
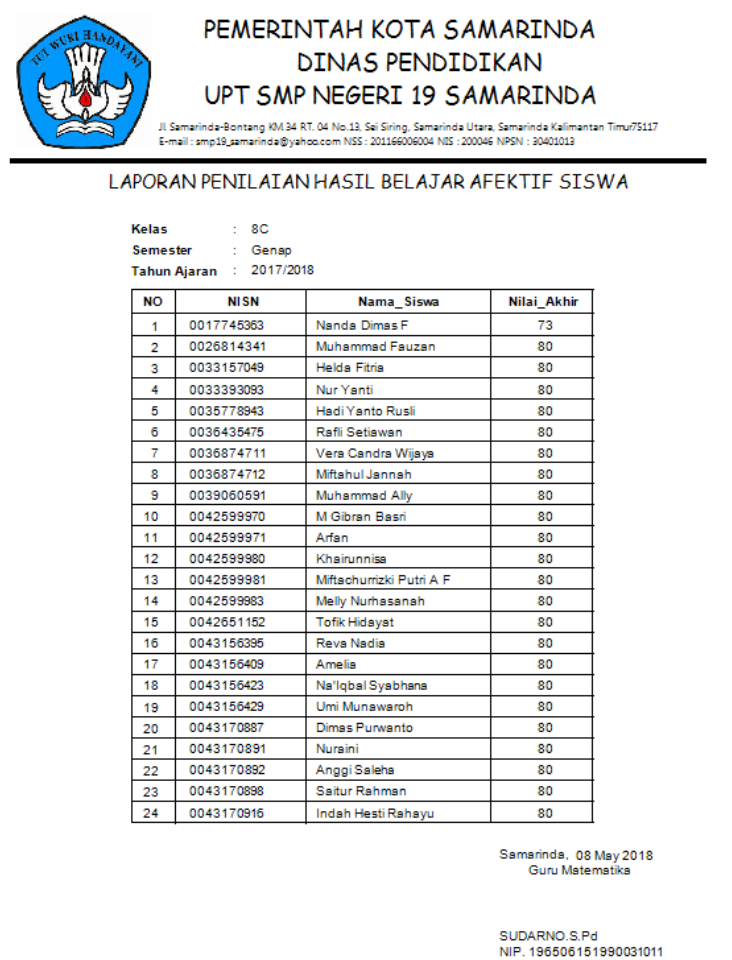

\section{Gambar 11 Laporan Nilai Hasil Belajar}

\section{Afektif Siswa untuk User Guru Matematika}

8. Form Halaman Awal User Wali Kelas

Form Halaman Awal User Wali Kelas merupakan form yang akan muncul ketika user wali kelas telah login. Terdapat MenuStrip yang didalamnya terdapat item-item seperti : Item Edit Admin Wali Kelas untuk manmpilkan halaman edit user Wali Kelas, Item Laporan untuk menampilkan Form Laporan, Item LogOut untuk keluar sebagai user guru matematika, dan Item Exit untuk keluar langsung dari aplikasi. Tampilan Form Halaman Halama Awal User Guru Matematika dapat dilihat seperti pada gambar 12 .

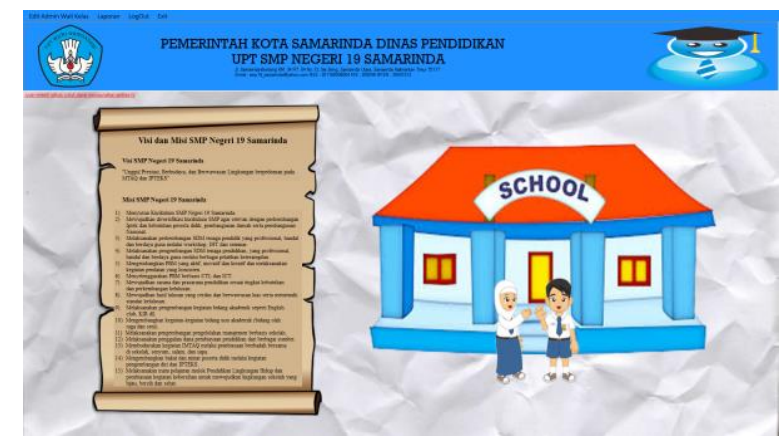

\section{Gambar 12 Form Halaman Awal User Wali Kelas}

9. Form Laporan untuk User Wali Kelas

Form Laporan adalah form dimana user wali kelas dapat memilih data yang akan di cetak. User dapat memilih laporan data siswa atau laporan nilai siswa. Button cetak yang bergambarkan print untuk mencetak data yang telah dipilih oleh user. Dan terdapat MenuStrip yang didalam ada Item Home dan Laporan. Tampilan Form Laporan dapat dilihat seperti pada gambar 13 .

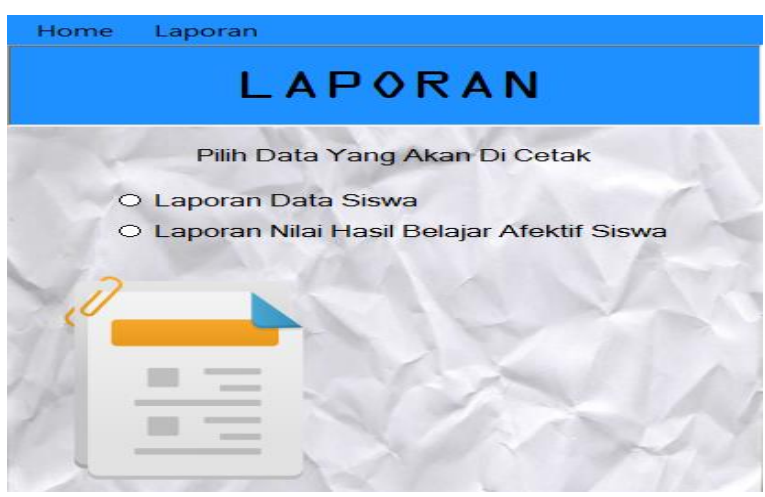

Gambar 12 Form Laporan untuk User Wali Kelas

10. Tampilan Form Laporan Data Siswa untuk User Wali Kelas

Pada gambar 13 adalah tampilan contoh laporan data siswa. 


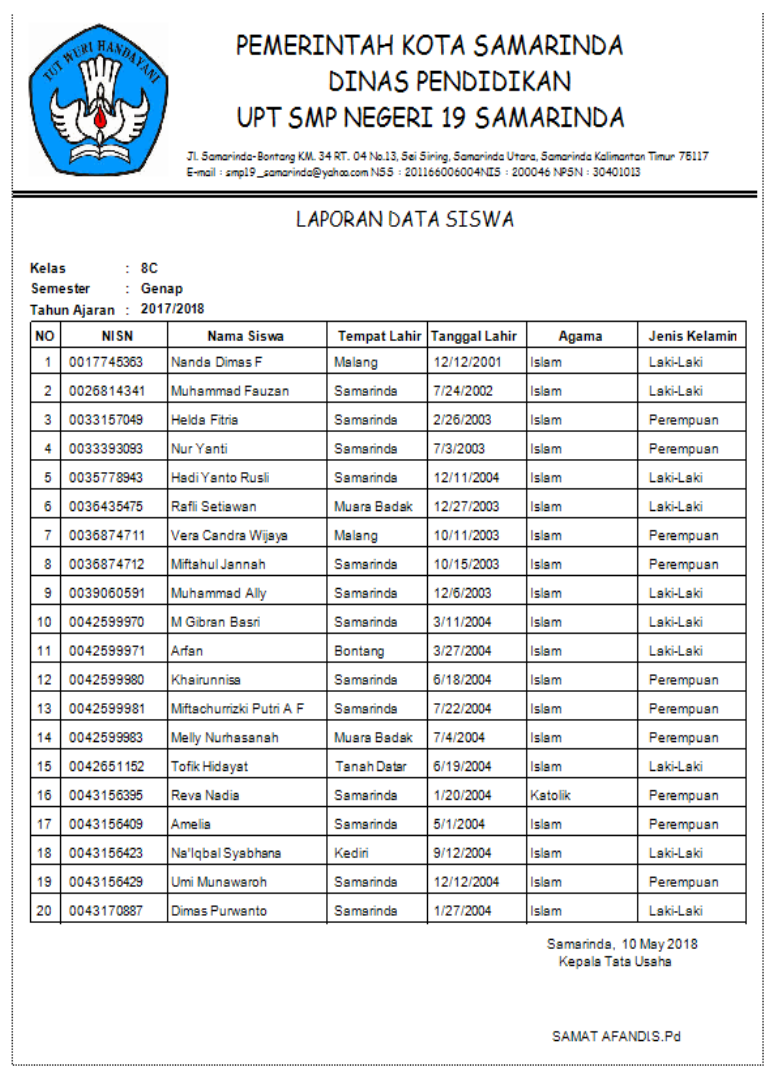

\section{Gambar 13 Laporan Data Siswa untuk User}

\section{Wali Kelas}

11. Tampilan Form Laporan Nilai Hasil Belajar Afektif Siswa untuk User Wali Kelas

Pada gambar 14 merupakan tampilan form cetak Laporan Nilai Hasil Belajar Afektif Siswa yang di cetak berdasarkan kelas, semester dan tahun ajaran. Pada gambar 15 adalah tampilan contoh laporan nilai hasil belajar afektif siswa.

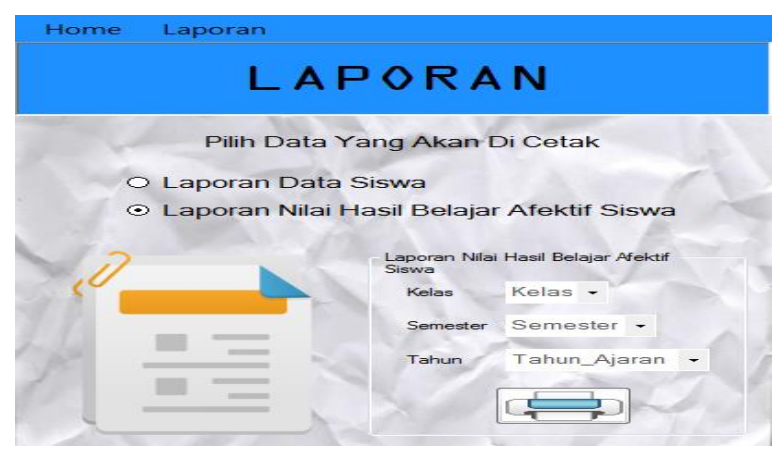

Gambar 14 Form Laporan Nilai Hasil Belajar Afektif Siswa untuk User Wali Kelas

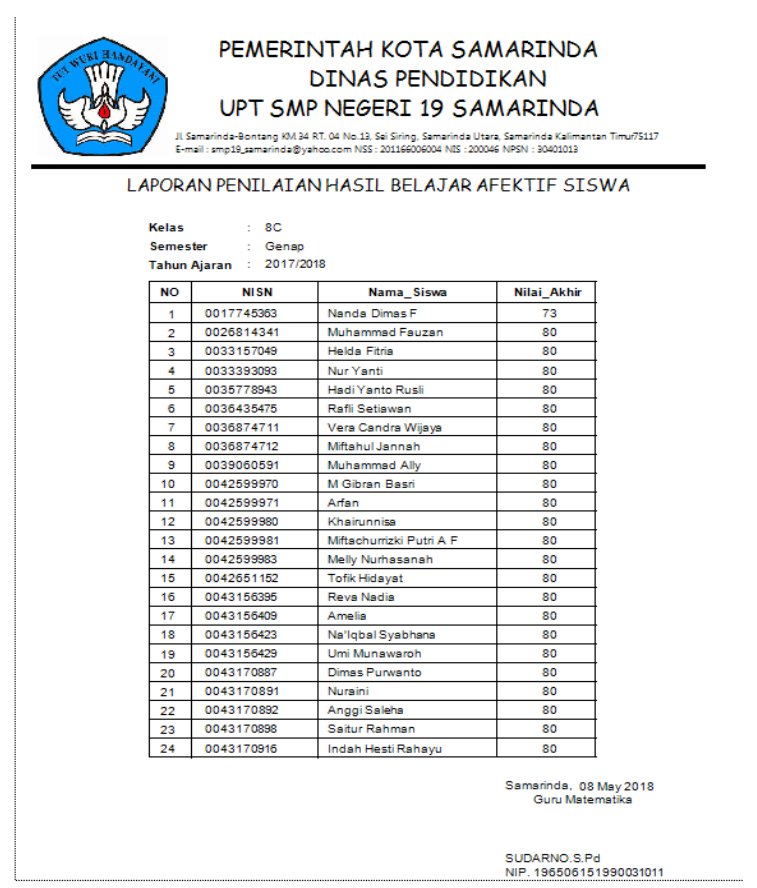

\section{Gambar 15 Laporan Nilai Hasil Belajar \\ Afektif Siswa untuk User Wali Kelas}

\section{KESIMPULAN}

Membangun sebuah aplikasi penilaian hasil belajar afektif untuk membantu guru dalam melakukan penilaian kepada siswa-siswi dengan cmenggunakan rubrik penilaian afektif dan menggunakan metode pengembangan sistem yaitu dengan Model Air Terjun (Waterfall). Aplikasi ini menggunakan tiga user yaitu user TU untuk menginputkan data siswa dan melihat laporan data siswa, user Guru Matematika untuk melakukan penilaian dan melihat laporan nilai hasil belajar afektif siswa dan user Wali Kelas untuk melihat laporan data siswa dan laporan nilai hasil belajar afektif siswa. Aplikasi ini hanya digunakan untuk aplikasi bantu untuk memberikan penilaian hasil belajar afektif pada siswa. 


\section{DAFTAR PUSTAKA}

[1] H. Ekawati, "Pengembangan Rubrik Hasil Belajar Matematika Untuk Aspek Kognitif Pada Materi Bangun Datar," Jurnal Pendas Mahakam, vol. 2, no. 1, p. 13, 2017.

[2] P. Rozak, "Evaluasi Afektif dalam Pembelajaran," Journal STIT Pemalang, vol. 4, no. 1, p. 20, 2014.

[3] I. Magdalena, "Penggunaan Instrument NonTes dalam Pembelajaran Bahasa Indonesia untuk Menilai Ranah Afektif Siswa SDN Karangsari 1 Tangerang," Jurnal Halaqah, vol. 2, no. 3, p. 13, 2020.

[4] R. H. Hutapea, "Instrumen Evaluasi Non-Tes dalam Penilaian Hasil Belajar Ranah Afektif dan Psikomotorik," Jurnal Teologi dan Pendidikan Kristen Kontekstual, vol. 2, no. 2, p. 15, 2019.

[5] L. Yunita, "Penerapan Instrument Penilaian Ranah Afektif Siswa pada Praktikum Kimia di Sekolah," Prosiding Seminar Nasional Pendidikan FKIP UNTIRTA, 2017.

[6] R. Utari, "Taksonomi Bloom," Jurnal Pusdiklat KNPK. Acedemia Edu, 2011. 